\title{
Computer System Security Problem
}

National Cancer Institute

\section{Source}

National Cancer Institute. Computer System Security Problem. NCI Thesaurus. Code C64348.

Problem associated with unauthorized access to or modification of a software system resulting in a loss of confidentiality, integrity, or availability of written program code, application software, or data or entire device. 